\title{
Priority development of smalldam in Wonogiri regency
}

\author{
Fisnu Yudha Pramono ${ }^{1}$, Yunitta Chandra Sari $^{2}$, Suripin ${ }^{3}$ \\ ${ }^{1}$ Water Resources Consultant, Indonesia \\ ${ }^{2}$ BBWS Bengawan Solo, Indonesia \\ ${ }^{3}$ Department of Civil Engineering, Diponegoro University, Semarang, Indonesia
}

\begin{abstract}
The province of Central Java often experiences floods during the rainy season and drought in the dry season. To support the program, BBWS Bengawan Solo participated in building some small-dams in Solo basin watershed. For this plan to be realized there needs to be a preceded study to determine the locations of potential dams. The paper aims to identify potential small-dams in the Solo River Basin, particularly in the Wonogiri District, and to determine priorities for the sequence of development. The potential of the small-dams is roughly derived from public information, topographic maps, and ground surveys. Initially, based on public information and local government officials, 39 locations of small-dams were obtained. After analyzing the topographic map and ground checking, the potential locations were cut down to 13 sites. Five small-dams will be selected as the first priority. The priority is determined based on multiple criteria, which consisted of technical criteria (topography, geology, and hydrology) and non-technical criteria (drought, economy, social and environment). Assessment method was based on the scoring system on all criteria. The result found that the five most potential small-dams in Wonogiri District are Glimbung, Gompyong, Wungu, Weru, and Waru.
\end{abstract}

Keywords: multi criteria, smalldam, development priority.

\section{Introduction}

Wonogiri regency experiences frequent drought and water shortage especially during dry season where rain fall is inadequate. One way to cope is with the construction of smalldams. In line with the policy of Central Java Province Government, to build 1000 smalldams, the BBWS Bengawan Solo conducted a study to identify the potential sites of smalldams within the Bengawan Solo catchment area, as well as to prioritize the 5 top potentials. Hence, we conducted a study to get some locations that could be used for development of the smalldams. As a body responsible for drought problems in Wonogiri district, BBWS Bengawan Solo should survey smalldams development on potential areas. The entire smalldams are incapable of being built simultaneously because of the limited

\footnotetext{
* Corresponding author: fisnu.company@gmail.com
} 
budget. So, it is necessary to formulate the direction of priority of the smalldam developments following the amount of the available budget. Having a lot of potential locations of the smalldams available, it is necessary to prioritize and analyze its development by considering several factors.

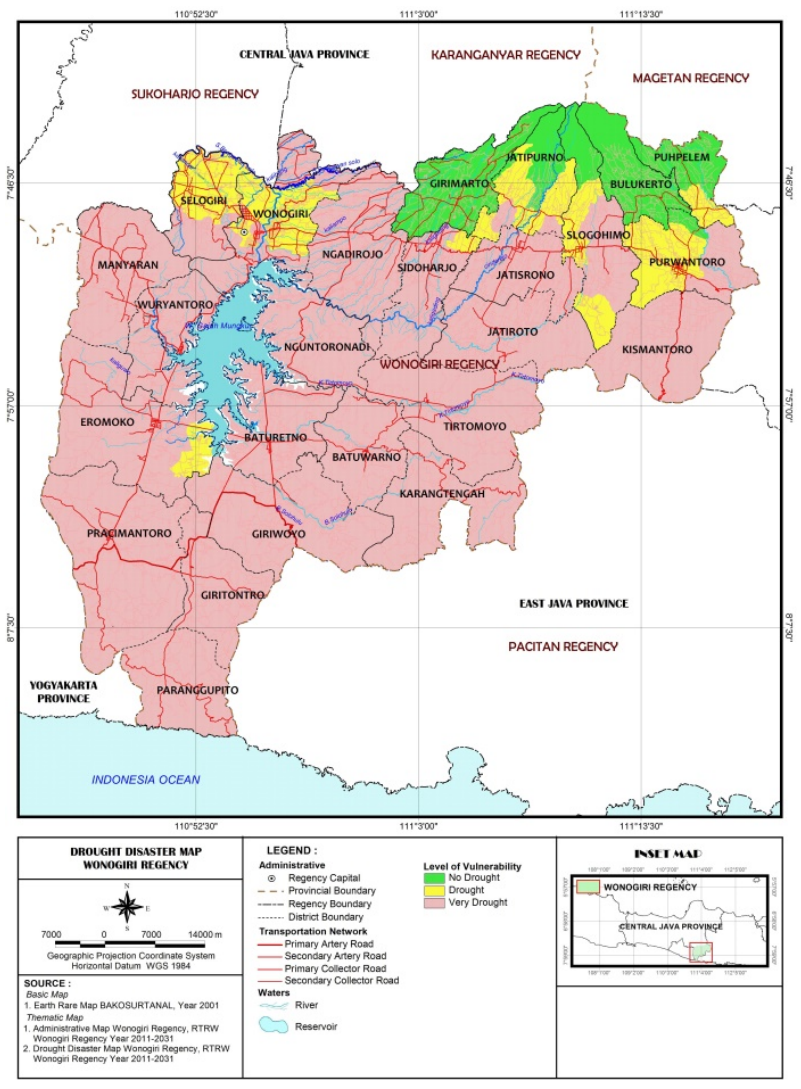

Fig. 1. Map of the drought-prone at Wonogiri regency.

Determining the highest priority of a smalldam development is essential because of the availability of fund and human resources, the multi-criteria model is indispensable [7]. Quantitative and qualitative data and expert judgments can contribute to make decisions in cases of incomplete data. Multi-criteria analysis allows decision-making when alternate numbers or criteria are usually conflicting.

Some of the known methods such as WEIGHTED AVERAGE, AHP, ELECTRE and PROMETHEE method are applicable in some of the different fields, even on the field of water resources management $[4,5,6,8]$. The models are different based on the mathematics and function as a rank determines.

[2] explained the strength and weakness of the MCDA method, described the model of the Weighted Sum Method-WSM, Analytic Hierarchy Process-AHP, ELECTRE, PROMETHEE.

Some of the researchers got attracted to applying the PROMETHEE method because it was designed to be perceivable [3]. This method is used in the various fields to determine the partial rank or complete rank from the alternative [1]. 


\subsection{Purpose and direction}

The purpose of this study is to conduct initial diligence from the preparation of decisionmaking tools to determine development priorities of Smalldam potential using multi-criteria analysis with the scoring method.

Based on the purpose of this study, it can be prepared for each stage of the study as follows:

- Determine the location potential smalldams with a land-based status.

- Analyze the water balance.

- Give weight to each criterion based on importance level.

- Analyze the value of the catch for each criterion.

- Determine the development priorities of potential smalldams.

\section{Method and materials}

Methodology of study or research implementation was carried out to achieve the objectives and purpose of the research. The study covers three steps:

1). Identification of the potential smalldams sites.

2). Collection of basic information data.

3). Analysis to determine the prioritization.

The method to be used in this study is a multi-criteria model since various aspects must be compared to each potential smalldam to obtain the top-five priority smalldams.

At first, we have to enter all the available data about potential smalldam in an inventory. Data on potential smalldams can be obtained from the local communities and agences such as: water resources management office (Dinas PSDA); energy and mineral resources office (Dinas ESDM); local water company (PDAM); Department of Agriculture; Public Works Service. From the several agencies that have provided data, we can run analysis based on the data they provide.

They also provide data about the land status. This means that the land status is the significant factor in determining the potential smalldams to be the priority smalldams. If the land status of the location is the village treasury, it will not be part of the smalldams priority.

Aspects to be considered include technical and non-technical aspects, from which each aspect can be divided into several criteria and redeveloped into several sub-criteria. According to the sub-criteria, it will be scored from each sub-criterion. From each subcriterion also weighted by considering the importance of the sub-criteria.

\section{Analysis}

\subsection{Inventory of potential smalldams}

Inventory of Potential Smalldams is the first step to determine priority smalldams. From the inventory, the result of all the locations will be known and the areas with the potential to become Smalldams. The result is not only from the just analysis, rather, relevant information gathered from the other stakeholder who will build and exploit the smalldams. Many potential smalldams were found at the location of the study and they numbered about 39 pieces gathered from the Water Resources Management Office in Central Java and Energy and Mineral Resources Office in Wonogiri Regency. 


\subsection{Check land status}

From the inventory result, the data of land ownership from the location plan of smalldams and the access roads shall be cleared. If the village treasury owns the land, then the smalldams will be removed from the list of priority smalldams. Due to this, it will be difficult to implement. So, the land to be used is the land of the society. According to land ownership status, the number of potential smalldams decreased from 39 to 13 pieces. Here are the potential smalldams:

Table 1. List of the potential smalldams.

\begin{tabular}{|c|l|}
\hline Number & \multicolumn{1}{|c|}{ Potential of Smalldams } \\
\hline 1 & Smalldam of Bangkan \\
\hline 2 & Smalldam of Bowong \\
\hline 3 & Smalldam of Seruni \\
\hline 4 & Smalldam of Waru \\
\hline 5 & Smalldam of Wungu \\
\hline 6 & Smalldam of Glimbung \\
\hline 7 & Smalldam of Gompyong \\
\hline 8 & Smalldam of Weru \\
\hline 9 & Smalldam of Baksari \\
\hline 10 & Smalldam of Gunung Bromo \\
\hline 11 & Smalldam of Jalakan \\
\hline 12 & Smalldam of Pogog \\
\hline 13 & Smalldam of Simpar \\
\hline
\end{tabular}




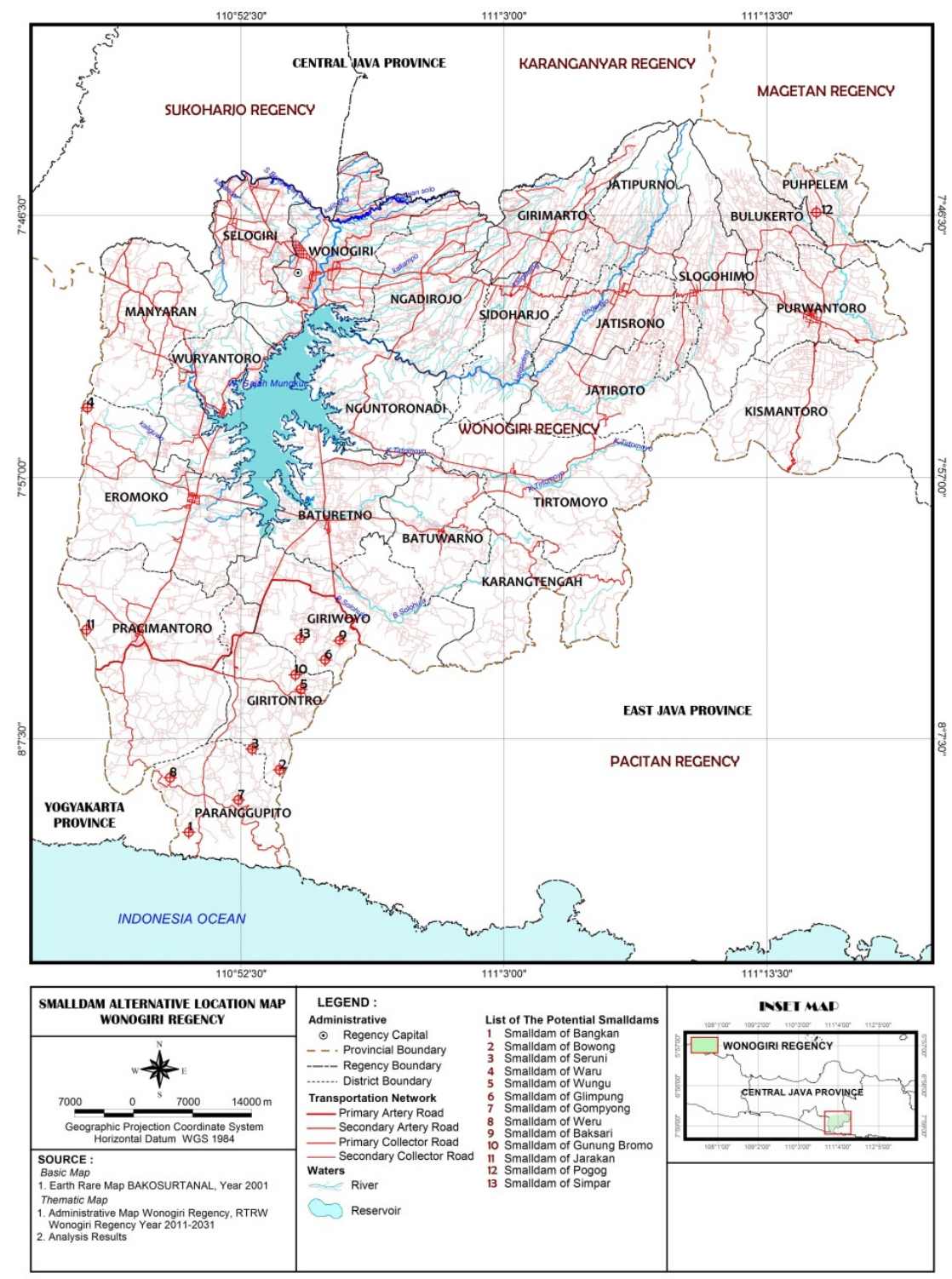

Fig. 2. Location of the potential smalldams (13 smalldams).

\subsection{Identification}

Based on the data from the inventory, there are some technical data that have to be noted from each smalldams potential: the depth of the smalldams, area of the inundation, volume of the storage. Not just the technical data but also non-technical data should also be prioritized and collected. 


\subsection{Scoring}

Firstly, define criteria through a review of relevant literature. From initial identification of these criteria, then interviews with experts, i.e. people who are considered to be a true understanding of the problem discussed, those directly feeling the effects of a problem and those who have interests about the problem. In this study, interviews were conducted with the experts (universities), practitioners from technical institutions related. The results of this discussion were then carried out from the formulation of the criteria that will subsequently be used in making questionnaires. A questionnaire is designed in such a way that the answer choice will be generated based on the level of its importance to the substance of the question questionnaires using Likert scale i.e.:

- $\quad$ Score 3 to declare a very level important

- Score 2 to state an important level

- Score 1 to declare the level sufficient important

- Score 0 to declare no level important

Below are some scoring of some aspects:

Table 2. Scoring of the geology structure.

\begin{tabular}{|c|l|c|}
\hline Number & \multicolumn{1}{|c|}{ Sub-criteria } & Scoring \\
\hline 1 & Cannot be repaired & 0 \\
\hline 2 & need repaired & 1 \\
\hline 3 & Fault & 2 \\
\hline 4 & No fault & 3 \\
\hline
\end{tabular}

Table 3. Scoring of the drought.

\begin{tabular}{|c|l|c|}
\hline Number & \multicolumn{1}{|c|}{ Sub-criteria } & Scoring \\
\hline 1 & None drought & 0 \\
\hline 2 & Slight drought & 1 \\
\hline 3 & Drought & 2 \\
\hline 4 & Heavy drought & 3 \\
\hline
\end{tabular}

Table 4. Scoring of the soil type.

\begin{tabular}{|c|l|c|}
\hline Number & \multicolumn{1}{|c|}{ Sub-criteria } & Scoring \\
\hline 1 & High permeability & 0 \\
\hline 2 & Middle permeability & 1 \\
\hline 3 & small permeability & 2 \\
\hline 4 & Waterproof & 3 \\
\hline
\end{tabular}

Table 5. Scoring of the landslide symptoms.

\begin{tabular}{|c|l|c|}
\hline Number & \multicolumn{1}{|c|}{ Sub-criteria } & Scoring \\
\hline 1 & Avalanche & 0 \\
\hline 2 & High Avalanche Potential & 1 \\
\hline 3 & Small Avalanche Potential & 2 \\
\hline 4 & Non-permeability & 3 \\
\hline
\end{tabular}


Table 6. Scoring of the high embankment.

\begin{tabular}{|c|l|c|}
\hline Number & \multicolumn{1}{|c|}{ Sub-criteria } & Scoring \\
\hline 1 & $>15.00$ & 0 \\
\hline 2 & 10,01 up to 15,00 & 1 \\
\hline 3 & 5.01 up to 10.00 & 2 \\
\hline 4 & $<5.00$ & 3 \\
\hline
\end{tabular}

Table 7. Scoring of the storage volume.

\begin{tabular}{|c|l|c|}
\hline Number & \multicolumn{1}{|c|}{ Sub-criteria } & Scoring \\
\hline 1 & $>500$ & 0 \\
\hline 2 & $<100$ & 1 \\
\hline 3 & 100 up to 300 & 2 \\
\hline 4 & 300 up to 500 & 3 \\
\hline
\end{tabular}

Table 8. Scoring of the number of beneficiaries.

\begin{tabular}{|c|l|c|}
\hline Number & \multicolumn{1}{|c|}{ Sub-criteria } & Scoring \\
\hline 1 & $<100$ family head & 0 \\
\hline 2 & $100-499$ family head & 1 \\
\hline 3 & $500-999$ family head & 2 \\
\hline 4 & $>1000$ family head & 3 \\
\hline
\end{tabular}

\subsection{Weighting}

After the scores were obtained from each sub-criterion, the next was the weighting. This weighting uses the Weighted Average method because it is easy in application and can be adjusted with an important aspect. Here's the weight of each sub-criteria from an expert.

Table 9. Weighted for each sub-criteria.

\begin{tabular}{|c|l|l|c|}
\hline Aspect & \multicolumn{1}{|c|}{ Criteria } & \multicolumn{1}{|c|}{ Sub-criteria } & Weight \\
\hline $\begin{array}{c}\text { Technical } \\
(40 \%)\end{array}$ & Topography & Volume ratio & 5 \\
\hline \multirow{5}{*}{} & & High Embankment & 5 \\
\cline { 3 - 4 } & Geology & Storage & 5 \\
\cline { 2 - 4 } & & Geology structure & 3 \\
\cline { 2 - 4 } & Hydrology & Soil type & 5 \\
\cline { 3 - 4 } & Landslide Symptoms & 2 \\
\cline { 2 - 4 } & Ground Water & 3 \\
\hline \multirow{2}{*}{$\begin{array}{c}\text { Non- } \\
\text { technical } \\
(60 \%)\end{array}$} & Material and Infrastructure & Mater balance & 3 \\
\cline { 3 - 4 } & & erosion & 2 \\
\cline { 3 - 4 } & & Existing system & 2 \\
\hline
\end{tabular}




\begin{tabular}{|l|l|l|c|}
\hline Aspect & \multicolumn{1}{|c|}{ Criteria } & \multicolumn{1}{c|}{ Sub-criteria } & Weight \\
\hline \multirow{4}{*}{} & & Access Distance & 2 \\
\cline { 3 - 4 } & & Accessibility & 2 \\
\cline { 3 - 4 } & & Length of Embankment & 2 \\
\cline { 3 - 4 } & & High Embankment & 2 \\
\cline { 2 - 4 } & \multirow{3}{*}{ Social and Environment } & Community Support & 10 \\
\cline { 3 - 4 } & & Resettlement & 5 \\
\hline & & Existing Buildings & 5 \\
\hline & Drought & Drought & 30 \\
\hline
\end{tabular}

\subsection{Smalldam priority}

After the scores obtained from each sub-criteria is multiplied by the weight that has been given based on the consideration of the experts, the result will be the total score when ranking from the highest overall score to the lowest. According to the check land status result, 13 smalldams will be analyzed to become top five priorities. Following this methodology, here is the result for smalldam's priority list:

Table 10. Result of the smalldam's ranking.

\begin{tabular}{|c|l|c|c|}
\hline Number & \multicolumn{1}{|c|}{ Potential of Smalldams } & $\begin{array}{c}\text { Total } \\
\text { Score }\end{array}$ & Ranking \\
\hline 1 & Smalldam of Bangkan & 0.493 & 6 \\
\hline 2 & Smalldam of Bowong & 0.492 & 7 \\
\hline 3 & Smalldam of Seruni & 0.479 & 9 \\
\hline 4 & Smalldam of Waru & 0.543 & 5 \\
\hline 5 & Smalldam of Wungu & 0.556 & 3 \\
\hline 6 & Smalldam of Glimbung & 0.563 & 1 \\
\hline 7 & Smalldam of Gompyong & 0.556 & 2 \\
\hline 8 & Smalldam of Weru & 0.553 & 4 \\
\hline 9 & Smalldam of Baksari & 0.469 & 12 \\
\hline 10 & Smalldam of Gunung Bromo & 0.473 & 10 \\
\hline 11 & Smalldam of Jalakan & 0.486 & 8 \\
\hline 12 & Smalldam of Pogog & 0.423 & 13 \\
\hline 13 & Smalldam of Simpar & 0.476 & 11 \\
\hline
\end{tabular}

From the calculated results, it can be concluded that from 13 smalldam taken only 5 topped smalldam, such as:

1). Smalldam of Glimbung

2). Smalldam of Gompyong

3). Smalldam of Wungu

4). Smalldam of Weru

5). Smalldam of Waru 


\section{Conclusion}

Prioritization analysis uses the simplest method for communities and various stakeholders to easily follow the analytical process. Multi-Criteria Method is the easiest method to understand. The conclusions from this study are:

- Weights for each criterion based on their importance here is the influence of the subjectivity of the decision maker or by the expert.

- Priority of the development of smalldams is determined based on the total rank/score multiplied by the weight of each criterion.

- From several locations that have been analyzed, here are the five smalldams that will be the top priority to be built:

○ Smalldams of Glimbung

- Smalldams of Gompyong

- Smalldams of Wungu

- Smalldams of Weru

- Smalldams of Waru

Many thanks to BBWS Bengawan Solo; Water Resources Management Office in Central Java; Energy and Mineral Resources Office in Wonogiri Regency, for providing assistance in conducting this research.

\section{References}

1. Behzadian, M. K. PROMETHEE: Acomprehensive literature review on methodologies and applications. EuropeanJournal of Operational Research, 198-215 (2010).

2. Belton, V. Multiple Criteria Decision Analysis: An integrated Approach. Boston: Kluwer Academic Publisher (2002).

3. Brans, J. P. A preference ranking organization method (ThePROMETHEE method for multiple criteria decision-making). Management Science, 647-656, (1985)

4. Grau, J. B. An application of mathematical models to select the optimal alternative foran integral part to desertification and erosion control (Chaco area - Salta Province Argentina). Biogeosciences, 3421-3433, (2010)

5. Krois, J. GIS-based multi-criteria evaluation to identify potentialsite for soil and water conservation techniques in the Ronquillo watershed, northernPeru. Applied Geography, 131-142, (2014)

6. Macary, F. O. A multicriteria spatial analysis of erosionrisk into small watersheds in the low Normandy bocage (France) by ELECTRE IIImethod coupled with a GIS. International Journal of Multicriteria Decision Making, 25-48, (2010)

7. Tijana Vulević, N. D. Multi-criteria decision analysis for sub-watersheds ranking via the PROMETHEE method. International Soil and Water Conservation Research Journal (2017)

8. Vulević, T. D. Prioritization of soil erosion vulnerable areas using multi-criteria analysis methods. Polish Journal of Environmental Studies, 317-323, (2015) 